\title{
THE INFLUENCE OF PHOSPHOLIPID-CONTAINING PREPARATIONS ON THE LEVEL OF IMMUNOGLOBULIN M IN THE SERUM OF BLOOD OF CALVES DURING THE PERIOD OF FORMATION OF COLOSTRAL IMMUNITY
}

\author{
S. I. Golopura, B. V. Popadiuk, M. I. Tsvilihovsky \\ golopura@ukr.net
}

National university of life and environmental sciences of Ukraine, 16 Polkovnyka Potekhina str., Kyiv 03041, Ukraine

The results of application of preparation "Membranostabil" and phospholipid-bilayer macrocapsules on the base of soy-bean lecithin developed by us with the aim of correction of indexes of content of immunoglobulin Min the blood of newborn calves during formation of colostral immunity is shown. The indexes of content of immunoglobulin $M$ in the serum of blood of the newborn calves in dynamic were investigated - from birth till the $11^{\text {th }}$ day of life.

The research was conducted on the three of groups of calves (the control one and two research) of Ukrainian black and white milk breed with drawing of blood samples from the jugular vein. Immunoglobulins $M$ were examined by gel electrophoresis in a thin layer of a polyacrylamide gel. Quantitative estimation of protein fractions was carried out by scanning of the electrophoregrams with subsequent reconstructing of them graphically and calculating by relative units or area using a computer program.

The results have proved that the preparation "Membranostabil" and phospholipid-bilayer macrocapsules based on soy-bean lecithin activate transport of immunoglobulins in small intestine and promote veracious increasing of the content of immunoglobulin M compared to the control group. The content of immunoglobulin M in the serum of newborn calves in both of the research groups at the age of 6 hours credibly increased and was higher during the whole period of the research except for calves of the $1^{\text {st }}$ research group at the age of 7 days compared to the calves of the control group. The dynamic with comparative analysis of content of immunoglobulin Min the serum of blood between different groups of calves of control and research groups is shown. The increasing of the content of immunoglobulin M in blood of newborn calves prevents development of digestive disorders in these animals.

Keywords: COLOSTRAL IMMUNITY, COLOSTRUM, BLOOD SERUM, IMMUNOGLOBULIN M, NEWBORN CALVES

\section{ВЛПЛИВ ФОСФОЛІПІДВМСНИХ ПРЕПАРАТІВ НА РІВЕНЬ ІМУНОГЛОБУЛІНУ М В СИРОВАТЦІ КРОВІ ТЕЛЯТ У ПЕРІОД ФОРМУВАННЯ КОЛОСТРАЛЬНОГО ІМУНІТЕТУ}

\author{
С. І. Голопура, Б. В. Попадюк, М. І. Цвіліховський \\ golopura@ukr.net
}

Національний університет біоресурсів і природокористування України, вул. Полковника Потєхіна, 16, м. Київ, 03041, Україна

Наведені результати застосування розробленого нами препарату «Мембраностабіл» $і$ фосфоліпідбімарових макрокапсул на основі соєвого лечитину для корекиії показників вмісту імуноглобуліну М в крові новонароджених телят в період формування колострального імунітету. Досліджені показники вмісту імуноглобуліну М у сироватиі крові новонароджених телят у динаміиі від народження до 11-добового віку.

Дослідження проводили на трьох групах телят (контроль та дві дослідні) украӥнської чорнорябої молочної породи з відбором в них зразків крові з яремної вени. Рівень імуноглобуліну М досліджували методом гель-електрофорезу в тонкому шарі поліакриламідного гелю. Кількісну оцінку білкових фракиій проводили скануванням електрофореграми з наступною реконструкиією їх графічно і обчисленням за відносними одиницями або площею з використанням комп 'ютерної програми.

Показано, щео препарат «Мембраностабіл» і фосфоліпід-бімарові макрокапсули на основі соєвого лецитину активують транспорт імуноглобулінів в тонкому кишечнику і сприяють вірогідному зростанню вмісту імуноглобуліну М порівняно з телятами контрольної групи. Вміст імуноглобуліну Му сироватиі крові новонароджених телят обох дослідних груп у вічі 6 годин вірогідно зріс $і$ залишався вищим впродовж всього періоду досліду, за винятком телят першої дослідної групи у віщъі 7 діб порівняно з телятами контрольної 
групи. Показана динаміка з порівняльним аналізом вмісту імуноглобуліну М в сироватщі крові між окремими групами телят, контрольної та дослідних груп. Зростання вмісту імуноглобуліну Мв крові новонароджених телят є одним із факторів, щьо забезпечує профілактику розладів травлення у изих тварин.

Ключові слова: КОЛОСТРАЛЬНИЙ ІМУНІТЕТ, МОЛОЗИВО, СИРОВАТКА КРОВІ, ІМУНОГЛОБУЛІН М, НОВОНАРОДЖЕНІ ТЕЛЯТА

\title{
ВЛИЯНИЕ ФОСФОЛИПИДСОДЕРЖАЩИХ ПРЕПАРАТОВ НА УРОВЕНЬ ИММУНОГЛОБУЛИНА М В СЫВОРОТКЕ КРОВИ ТЕЛЯТ В ПЕРИОД ФОРМИРОВАНИЯ КОЛОСТРАЛЬНОГО ИММУНИТЕТА
}

\author{
С. И. Голопура, Б. В. Попадюк, Н. И. Цвилиховский \\ golopura@ukr.net
}

Национальный университет биоресурсов и природопользования Украины, ул. Полковника Потехина, 16, г. Киев, 03041, Украина

Приведены результаты применения разработанного нами препарата «Мембраностабил» и фосфолипид-бислойныхх макрокапсул на основе соевого лецитина для коррекиии показателей содержсания иммуноглобулина Мв крови новорожденных телят в период формирования колострального иммунитета. Исследованы показатели содержания иммуноглобулина М в сыворотке крови новорожденных телят в динамике от рождения до 11-суточного возраста.

Исследования проводили на трех группах телят (контроль и две опьтные) украинской черно-пестрой породы с отбором образиов крови с яремной вены. Содержание иммуноглобулина М исследовали методом гель-электрофореза в тонком слое полиакриламидного геля. Количественную оценку белковых фракций проводили сканированием электрофореграмм с последующим реконструированием их графически и вычислением за относительными единицами или площадью с использованием компьютерной программы.

Показано, что препарат «Мембраностабил» и фосфолипид-бислойные макрокапсульь на основе соевого лецитина активируют транспорт иммуноглобулинов в тонком кишечнике и способствуют достоверному увеличению содержания иммуноглобулина М в сравнении с телятами контрольной группы. Содержание иммуноглобулина М в сыворотке крови новорожденных телят обеих опытных групп в возрасте 6 часов достоверно увеличилось и осталось высоким на протяэсении всего периода опыта за исключением телят первой опьттной группы в возрасте 7 суток в сравнении с телятами контрольной группь. Показана динамика со сравнительными анализом содержсимого иммуноглобулина М в сыворотке крови межну контрольной и опьтными группами телят. Увеличение содержания иммуноглобулина М в крови новорожденных телят является одним из факторов, который обеспечивает профилактику расстройств пищеварения у этих животных.

\section{КЛючевЫе слова: КОЛОСТРАЛЬНЫЙ ИММУНИТЕТ, МОЛОЗИВО, СЫВОРОТКА КРО- ВИ, ИММУНОГЛОБУЛИН М, НОВОРОЖДЕННЫЕ ТЕЛЯТА}

The study of the level of immunoglobulins (Ig) in the blood of animals of different classes, species, and age groups, since their birth, is of great importance for understanding the processes of the formation of the immunological status of the organism during the postnatal period [1].

The blood of animals contains $2-6 \%$ of IgM. This is the first class of immunoglobulins that appears in the blood of animals after their immunization. Then, in 2-3 days, more intense and prolonged formation of IgG and immunoglobulins of other classes begins. IgM and IgG molecules are embedded in the plasma membrane of B-lymphocytes and are antigen-specific receptors.
IgM is more effective in reactions of hemolysis and bacterial lysis [2]. Ig of class $M$ are crucial in the prevention of colipsepsis, and Ig of classes $G$ and $\mathrm{A}-$ in the prevention of other intestinal infections and the neutralization of toxins [2]. Thus, most researchers the septic form of colibacillosis of calves connect with the deficiency of immunoglobulin M, and enteritis - with the deficiency of immunoglobulins G and A. Such a role of different classes of immunoglobulins should be taken into account in the development of preventive measures, diagnosis, and treatment [10].

It is very important that IgM is more efficiently absorbed in the intestine of animals within 
6 hours after their birth $(63.8 \%)$, compared to $\operatorname{IgA}(47 \%)$ or $\operatorname{IgG}(11.19 \%)$. Despite the small amount of IgM, which is transmitted with colostrum to calves compared to $\mathrm{IgG}$, it has a very big impact on the safety of calves. Thus, according to some researchers [2], the serum concentration of $\mathrm{IgG}$ in the dead calves was $2.26, \operatorname{IgA}-3.44$ and $\operatorname{IgM}-5.74$ times less, than in clinically healthy animals. At the same time, the level of catabolism of total immunoglobulins in the group of survived calves was 1.12 , and $\operatorname{IgM}-4.64$ times higher, than in the group of dead calves [10].

In this connection, the quantitative determination of individual classes of immunoglobulins, as a method of studying of the state of humoral immunity, is now acquiring a particular importance in determination of the immunological resistance of the organism of newborn animals.

The purpose of the research was to study the indices of the content of immunoglobulins of class $\mathrm{M}$ in the serum of newborn calves during the formation of colostral immunity applying the preparation "Membranostabil" and phospholipidbilayer macrocapsules based on soybean lecithin with the colostrum.

\section{Materials and methods}

Experimental researches were conducted in the scientifically-research centre "Velykosnitinske n.a. O. V. Muzychenko", and laboratory ones in the research laboratory of the Department of Therapy and Clinical Diagnostics of the NUBiP of Ukraine. In the experiment calves from the birth till the age of 11 days were used. Three groups of calves (control and 2 experimental) were formed, 5 animals in each one. The calves of all groups were given to drink colostrums in the amount of $2 \mathrm{~L}$ after birth and then $1.5 \mathrm{~L}$ every 4 hours during the first day, and every 6 hours on the $2^{\text {nd }}$ and $3^{\text {rd }}$ days of life. At the age of 4 days, calves were passed to a 3-time feeding. Calves of the control group received the colostrum only. Calves of the $1^{\text {st }}$ experimental group twice, $15 \mathrm{~min}$ prior to the first drinking of the colostrum, and then in 12 hours, 15 min prior to drinking of the colostrums received per os phospholipid-bilayer macrocapsules of $46.5 \mathrm{~nm}$ in size prepared on the basis of soybean lecithin in a dose of $5 \mathrm{ml}$ with warm water $\left(\mathrm{t} 37^{\circ} \mathrm{C}\right)$.
Calves of the $2^{\text {nd }}$ experimental group twice, 15 min prior to the first drinking of the colostrum, and then in 12 hours, 15 min prior to drinking of the colostrums received per os the preparation "Membranostabil" developed by us on the basis of soybean lecithin, in a dose of $5 \mathrm{ml}$ with warm water $\left(\mathrm{t} 37^{\circ} \mathrm{C}\right)$. The preparation "Membranostabil" is a macrocapsule of phospholipid bilayer of $46.5 \mathrm{~nm}$ in size, which are filled with water-modifying form of vitamins $A-4000 \mathrm{IU}$ and $\mathrm{E}-15 \mathrm{mg}$.

Drawing of blood samples in calves was carried out from the jugular vein into the vacuum test tubes in $6,24,72$ hours on the $7^{\text {th }}$ and $11^{\text {th }}$ days of their life.

Immunoglobulin $\mathrm{M}$ were examined by gel electrophoresis in a thin layer of a polyacrylamide gel with a gradient concentration of $7-18 \%$, separating them by the molecular weight using sodium dodecyl sulfate (SDS) [3]. Protein zones were identified using reagent on amino acid — Kumasi G-250 (Serva), and the molecular weight was determined using markers of corp. Bioscience (Amersham), Sweden.

Quantitative estimation of protein fractions was carried out by scanning of the electrophoregrams with subsequent reconstructing of them graphically and calculating by relative units or area using a computer program. The total amount of proteins was taken as $100 \%$.

\section{Results and Discussion}

In the blood serum of newborn calves, before drinking of the colostrum, the content of immunoglobulin $\mathrm{M}$ was $0.26 \pm 0.012 \mathrm{~g} / \mathrm{L}$ (fig. 1). This indicates that the calves in the intrauterine period of development are synthesizing their own IgM

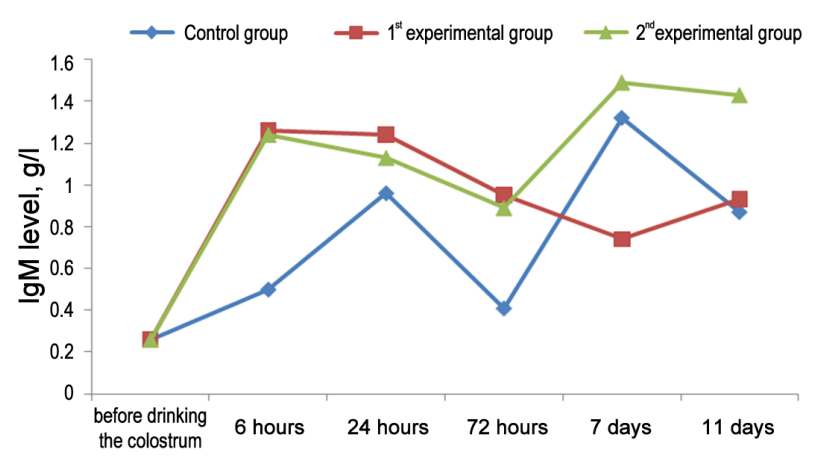

Fig. 1. The level of immunoglobulin M in the serum of newborn calves 
in small amounts, since the desmochorial type of the placenta of the cow is a barrier not only for such macromolecules as Ig M, but also for smaller molecules such as IgG [8] and IgA.

Active transport processes in the small intestine of newborn calves after drinking of the colostrum promote the rapid absorption of various proteins, especially colostrum Ig in the native state into the blood.

Thus, in the blood serum of the control group at the age of 6 hours, we found a significant increase in the IgM content in almost 2 times $(0.5 \pm 0.02 \mathrm{~g} / \mathrm{L}, \mathrm{P} \leq 0.001)$, and at the age of one day - almost 4 times $(0.95 \pm 0.04 \mathrm{~g} / \mathrm{L}, \mathrm{P} \leq 0.001)$ compared to the beginning of the research. After, there was a significant decrease in IgM concentration in the blood serum of these animals to a level of $0.4 \pm 0.029 \mathrm{~g} / \mathrm{L}$ on $72^{\text {th }}$ hour of their life. This can be explained by the short half-life of IgM, which is only $1-2$ days $[3,2]$, and the lack of intensive synthesis of its own antibodies. Thus, according to the data of some researchers [3], at a high level of providing of calves with colostrum immunoglobulins, the synthesis of their own Ig in their body begins at the age of 1-2 weeks, whereas in calves that have not received colostrum - from the fourth day of life. On the $7^{\text {th }}$ day, the IgM level in the blood serum of calves from control group significantly increased to $1.31 \pm 0.04 \mathrm{~g} / \mathrm{L}$. In our opinion, and also according to the data of other researchers [5], this may be a consequence of the own synthesis of IgM, as a marker for the introduction of microbial agents into the body of calves. As a consequence, clinically in the calves of the control group during this period, we noted diarrhea and symptoms of intoxication of their organism.

In the blood serum of newborn calves of the $1^{\text {st }}$ experimental group applied phospholipidbilayer macrocapsules, a significant increase in IgM concentration $4.85(1.26 \pm 0.04 \mathrm{~g} / \mathrm{L}, \mathrm{P} \leq 0.001)$ and 4.73 times $(1.23 \pm 0.03 \mathrm{~g} / \mathrm{L}, \mathrm{P} \leq 0.001)$ at the $6^{\text {th }}$ and $24^{\text {th }}$ hour of their life, respectively, compared to the beginning of the research. In this case, the content of IgM in the calves of the $1^{\text {st }}$ experimental group was significantly higher 2.52 and 1.29 times at the age of 6 and 24 hours, respectively, compared with the calves of the control group. Subsequently, there was a gradual decrease in the concentration of $\operatorname{IgM}$ in the blood serum of these animals to a level of $0.78 \pm 0.03 \mathrm{~g} / \mathrm{L}$, followed by an increase in the IgM level to $0.92 \pm 0.02 \mathrm{~g} / \mathrm{L}$ at the age of 11 days (fig. 1). It should be noted that digestion disorders or signs of other diseases of the early postnatal period were not observed in the calves of the $1^{\text {st }}$ experimental group [9].

In the serum of the calves of the $2^{\text {nd }}$ experimental group, under the influence of the preparation "Membranostabil" up to the $3^{\text {rd }}$ day of life, we established a tendency for the content of IgM, similar to the calves of the $1^{\text {st }}$ experimental group.

Thus, in the serum of these animals at the $6^{\text {th }}$ hour of life the IgM concentration increased from $0.26 \pm 0.012$ to $1.24 \pm 0.29 \mathrm{~g} / \mathrm{L}$, which is 2.48 times higher than in the control group of calves. At the age of 1-3 days, the IgM level in the blood serum of the calves of the $2^{\text {nd }}$ experimental group gradually decreased, to $1.13 \pm 0.02 \mathrm{~g} / \mathrm{L}$ and $0.84 \pm 0.02 \mathrm{~g} / \mathrm{L}$, respectively, after which it increased to $1.48 \pm 0.03$ on the $7^{\text {th }}$ day, remaining almost at the same level on the $11^{\text {th }}$ day (fig. 1). As in the calves of the $1^{\text {st }} \mathrm{ex}-$ perimental group, early neonatal diseases were not observed during the period from the beginning of the research to the $11^{\text {th }}$ day of life in the calves of the $2^{\text {nd }}$ experimental group.

Thus, the data obtained by us testify to more intensive transport of IgM of colostrum in the intestine of calves of the $1^{\text {st }}$ and $2^{\text {nd }}$ experimental groups that, in our opinion, is due to the use of experimental phospholipid-containing preparations in animals. High level of immunoglobulins of class $M$ in the blood of calves of experimental groups in the first three days after their birth contribute the prevention of the development of digestive disorders in these animals, the high probability of which could be provoked by pathogenic and opportunistic microorganisms that enter the digestive system of animals with the beginning of their trophic nutrition. On the other hand, a low IgM level in the blood serum of control group of calves could be one of the factors contributing to the development of digestive disorders in these animals. This was manifested in them on the $2^{\text {nd }}$ day of their life by a decrease in appetite; the suckling reflex was suppressed; the intestinal peristalsis was intensified; the defecation was frequent, and the feces - liquid, bright yellow colored. In calves around the anus appeared dirty with feces fur. The body temperature in the control group of calves was normal on the initial stage, and 
with the development of the disease, the temperature of the skin at certain places of the body (lower limbs, ears, nasal mirror) decreased.

In the calves of the $1^{\text {st }}$ experimental group the symptoms of diarrhea were not observed. Only in one of five calves participated in the experiment, small digestive disorders were noted that passed without complications and disappeared during the day. In the calves of the $2^{\text {nd }}$ experimental group digestive disorders and changes in the clinical state of the body were not observed during the researches.

\section{Conclusions}

The obtained data can indicate the membrane-stabilizing effect of the liposomal macrocapsular preparations used in our study, made on the basis of soybean lecithin. This action can be caused by the ability of phospholipids, which are part of these preparations, to maintain stable structure and viscosity of the plasmolemma of enterocytes. This, in turn, can determine the activity of the immunoreceptor proteins of the plasmolemma of enterocytes to colostrum immunoglobulins, promote the improvement of the transfer of especially heavy by the molecular mass immunoglobulins of $\mathrm{M}$ class (about $900 \mathrm{kDa}$ ), the formation of a sufficient level of colostral immunity, and the prevention of digestive disorders in newborn calves.

Perspectives of the future investigations. Taking into account obtained data about the change in concentration of immunoglobulin $\mathrm{M}$ in the serum of blood of the newborn calves under the action of the preparation "Membranostabil" and phospholipid bilayer macrocapsules based on the soybean lecithin, the next step of the research is the investigation of the influence of these preparations on the immunoglobulins of other classes. The influence of the preparation "Membranostabil" and phospholipid bilayer macrocapsules on the receptor proteins of the cytolemma of the enterocytes and other links of formation of colostral immunity will be investigated. In the prospective, it is planned to develop the scheme of the prophylaxis of disorders of the digestive system and immunodeficiency of newborn calves using the above-mentioned preparations.

1. Borzenko E. V. Quantitative characteristic of immunoglobulins in biological fluids of cattle by immunochemical analysis methods. Author's abstract. diss. cand. vet. Sciences. Moscow, 2005, 16 p. (in Russian)

2. Buchwalder R., Fuchs H., Haider H. Immunoprophylaxis of animal diseases. Ed. H. G. Gizatullin. Moscow, Kolos, 1981, 415 p. (in Russian)

3. Cervenak J., Kacskovics I. The neonatal Fc receptor plays a crucial role in the metabolism of $\mathrm{IgG}$ in livestock animals. Vet. Immunol. Immunopathol., 2009, vol. 128, pp. 171-177. DOI: 10.1016/j. vetimm.2008.10.300.

4. Hurley W. L., Theil P. K. Perspectives on Immunoglobulins in Colostrum and Milk. Nutrients, 2011, no. 3, pp. 442-474. DOI: 10.3390/nu3040442.

5. Jawor P., Stefaniak T., Mee J. F. Immune and inflammatory biomarkers in cases of bovine perinatal mortality with and without infection in utero. Dairy Science, 2017, vol. 100, issue 2, pp. 1408-1416. DOI: $10.3168 /$ jds.2016-11825.

6. Laemmli, U. K. Cleavage of structural proteins during the assembly of the head of bacteriophage. Nature, 1970 , vol. 4, issue 227, pp. 680-685. DOI: $10.1038 / 227680 \mathrm{a} 0$.

7. Levchenko V. I., Zayarnyuk V. P., Papchenko I. P. Gastrointestinal diseases of newborn calves. Method. recom. Bila Tzerkva, 1997, 81 p. (in Russian)

8. Mayasari N., Van Knegsel A. T. M., Reilingha G. de Vries, Kempa B., Parmentier H. K. Natural autoantibodies in Bos taurus calves during the first twelve weeks of life. Veterinary Immunology and Immunopathology, 2016, vol. 178, pp. 70-78. DOI: 10.1016/j. vetimm.2016.07.001.

9. Marynyuk M. O., Golopura S. I., Yakymchuk O. M., Nemova T. V., Tsvilihovsky M. I. Level of colostral immunity and development of digestive disorders in newborn calves. Veterinary medicine of Ukraine, 2014, no. 5, pp. 21-23. (in Ukrainian)

10. Zhosan N. S. The state of natural resistance and immunologic reactivity in newborn calves with colibacillosis. Dis. Doct. of vet. science on spec. 16.00.03 veterinary microbiology and virology, Chisinau, 1998, 227 p. (in Russian) 